\title{
The 4.2 ka event in the vegetation record of the central Mediterranean
}

\section{Federico Di Rita and Donatella Magri}

Department of Environmental Biology, Sapienza University of Rome, Rome, 00185, Italy

Correspondence: Federico Di Rita (federico.dirita@uniroma1.it)

Received: 28 September 2018 - Discussion started: 10 October 2018

Revised: 8 January 2019 - Accepted: 12 January 2019 - Published: 7 February 2019

\begin{abstract}
In this paper, the variation in forest cover in the central Mediterranean region, reflected by percentage changes in the arboreal pollen record, has been examined in relation to the $4.2 \mathrm{ka}$ event. A total of 36 well-dated and detailed pollen records from latitudes between 45 and $36^{\circ} \mathrm{N}$ were selected and their vegetation dynamics between 5 and $3 \mathrm{ka}$ examined in relation to the physiographic and climatic features of the study area and to the influence of human activity on past vegetation, as suggested by anthropogenic pollen indicators. We have found that the sites located between 43 and $45^{\circ} \mathrm{N}$ do not show any significant vegetation change in correspondence with the $4.2 \mathrm{ka}$ event. Several sites located on the Italian Peninsula between 39 and $43^{\circ} \mathrm{N}$ show a marked opening of the forest, suggesting a vegetation response to the climate instability of the $4.2 \mathrm{ka}$ event. Between 36 and $39^{\circ} \mathrm{N}$, a forest decline is always visible around $4.2 \mathrm{ka}$, and in some cases it is dramatic. This indicates that this region was severely affected by a climate change towards arid conditions that lasted a few hundred years and was followed by a recovery of forest vegetation in the Middle Bronze Age. Human activity, especially intense in southern Italy, may have been favored by this natural opening of vegetation. In Sardinia and Corsica, no clear change in vegetation is observed at the same time. We suggest that during the $4.2 \mathrm{ka}$ event southern Italy and Tunisia were under the prevalent influence of a north African climate system characterized by a persistent high-pressure cell.
\end{abstract}

\section{Introduction}

The so-called " $4.2 \mathrm{ka}$ event" has so far been observed in several pollen records from the central Mediterranean, where it has been described as a phase of temporary decline in arboreal pollen (AP) percentages, interpreted as an opening of the forest vegetation (Di Rita and Magri, 2009, 2012; Di Rita et al., 2018b). This paleovegetational event is more or less coeval to the drought event that has been recognized in the eastern Mediterranean regions (Kaniewski et al., 2018), in the Middle East (e.g., Weiss, 2017; Weiss et al., 1993; Cullen et al., 2000; Staubwasser et al., 2003), Africa (e.g., Marshall et. al., 2011), and South and East Asia (Liu and Feng, 2012; Dixit et al., 2014, 2018) and to widespread climate anomalies recorded at a global scale (e.g., Walker et al., 2012), including wetter climate conditions in the southwestern Mediterranean regions (Di Rita et al., 2018a; Zielhofer et al., 2018). A detailed review of pollen-independent key studies concerning the climatic and environmental changes occurring in the Mediterranean Basin between 4.3 and $3.8 \mathrm{ka}$ is available in this volume of Climate of the Past (Bini et al., 2018), to which we refer. Defining the temporal and geographical limits of this environmental change in the central Mediterranean, as well as its overall intensity and effects, may help us to better understand the causes and climate processes underlying the establishment and distribution of this event at a wider scale. Ages are always intended as cal BP throughout the paper.

The interest in studying the $4.2 \mathrm{ka}$ event in the central Mediterranean is further increased by the climate-sensitive position of this region, located at the interface between two large continents (Europe and Africa) and subject to climate influence from both the North Atlantic Oscillation (NAO) and the high pressures that dominate the Sahara. The bal- 
ance and complex interplay between these two patterns of atmospheric circulation determines the amount and seasonality of moisture availability in the region, and consequently the development or contraction of the forest vegetation. Recent studies have recognized that during the Holocene the northern and southern regions in the central Mediterranean have been under the prevalent influence of different climate patterns, producing opposite hydrological regimes and consequent vegetation dynamics (Magny et al., 2013; Di Rita et al., 2018a). The geographical distribution of rainfall, depending partly on the prevalent climate mode and partly on physiographical features, appears particularly important for the effects it may have on the vegetational landscape at middle latitudes. In the case of a climate shift towards aridity, the response of forest vegetation may be modest in areas with abundant water availability, while marked forest declines are expected in areas that suffer from water deficit. Considering that the modern mean annual precipitation in the central Mediterranean, ranging from $<300$ to $>2500 \mathrm{~mm}$ (Fig. 1), is largely conditioned by the orography of the region, it is reasonable to assume that in the past similarly different pluviometric regimes from one region to the other could also determine different responses of the forest vegetation to climate change.

Another feature peculiar to the central Mediterranean is the ability of vegetation to rapidly respond to climate change, being developed in a complex physiographic system that enhances high floristic diversity and admixtures of xerophilous and mesophilous plant assemblages often located in ecological niches close to each other (Magri et al., 2015). This pattern is the result of a long-term persistence of temperate, mediterranean, and steppe plant communities, which coexisted throughout the glacial-interglacial cycles of the Quaternary, ready to alternately develop following climate oscillations (Magri et al., 2017).

The vegetation history of the central Mediterranean is further complicated by a long-lasting and intense human impact on the landscape through agropastoral and silvicultural practices, forest clearance, fires, and demographic increase. In the central Mediterranean, the transition from Late $\mathrm{Ne}$ olithic or Chalcolithic cultures to metallurgic communities is dated at $4.5-4.2 \mathrm{ka}$ (ca. $2500-2200 \mathrm{BC}$ ), at the same time of marked openings of forests and the establishment of the first continuous records of anthropogenic indicators (Tinner et al., 2003; Carrión et al., 2010). Repeated openings of forests in an area spanning from Sicily to the Alps have been previously explained by the adoption of innovations and climatic impacts on prehistorical societies over wide areas (through harvest success and the resulting carrying capacity; Tinner et al., 2003, 2009). However, in the Balearic Islands climate conditions are considered preponderant over human activity to explain the vegetation changes around $4.2 \mathrm{ka}$ (Burjachs et al., 2017). Careful consideration of the geographical vegetation patterns and of the value of anthropogenic indicators, in relation to the archeological record, may help disentangle the

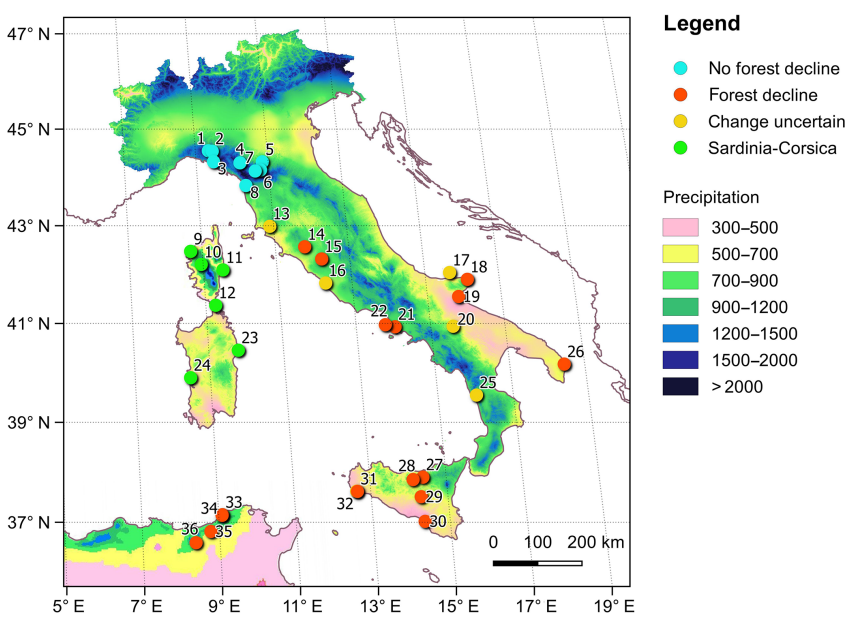

Figure 1. Map of the mean annual precipitation in the central Mediterranean (modified from Attorre et al., 2007, 2008; Benslimane et al., 2009; Smaoui, 2015; Poher, 2017). Dots represent the pollen sites selected for this work: 1. Mogge di Ertola: Guido et al. (2013); 2. Lago Riane: Branch (2013); 3. Lago di Bargone: Cruise et al. (2009); 4. Lago Padule: Watson (1996); 5. Pavullo nel Frignano: Vescovi et al. (2010a); 6. Ospitale: Watson (1996); 7. Lago del Greppo: Vescovi et al. (2010b); 8. Lago di Massaciuccoli: Colombaroli et al. (2007); 9. Crovani: Reille (1992); 10. Creno: Reille et al. (1999); 11. Aleria del Sale: Currás et al. (2017); 12. Greco Pond: Poher et al. (2017); 13. Lago dell'Accesa: Drescher-Schenider et al. (2007); Vannière et al. (2008); 14. Lagaccione: Magri (1999); 15. Lago di Vico: Magri and Sadori (1999); 16. Lingua d'Oca-Interporto: Di Rita et al. (2010); 17. RF93-30: Mercuri et al. (2012); 18. Lago Battaglia: Caroli and Caldara (2007); 19. Lago Salso: Di Rita et al. (2011); 20. Lago Grande di Monticchio: Allen et al. (2002); 21. Lago Patria: Di Rita et al. (2018c); 22. Golfo di Gaeta: Margaritelli et al. (2016); Di Rita et al. (2018b); 23. Sa Curcurica: Beffa et al. (2016); 24. Mistras Lagoon: Di Rita and Melis (2013); 25. Lago Trifoglietti: Joannin et al. (2012); 26. Lago Alimini Piccolo: Di Rita and Magri (2009); 27. Urio Quattrocchi: Bisculm et al. (2012); 28. Urgo Pietra Giordano: Tinner et al. (2016); 29. Lago di Pergusa: Sadori and Narcisi (2001); 30. Biviere di Gela: Noti et al. (2009); 31. Gorgo Basso: Tinner et al. (2009); 32. Lago Preola: Calò et al. (2012); 33. Majen El Orbi: Stambouli-Essassi et al. (2007); 34. Majen Ben H'mida: Stambouli-Essassi et al. (2007); 35. Dar Fatma I: Stambouli-Essassi et al. (2007); 36. Djebel Ghorra: Ben Tiba (1995); Stambouli-Essassi et al. (2007).

effects of human activity versus changes in temperature and precipitation when interpreting paleovegetational records.

Based on these premises, our aim is to verify to what extent the $4.2 \mathrm{ka}$ event affected the distribution of forests in the central Mediterranean region and to highlight possible geographical patterns that may reflect the responses of vegetation to changes in precipitation and water availability. 


\section{Materials and methods}

Following a careful screening of pollen records from Italy, Corsica, and Tunisia, a total of 36 records were selected for this work based on their geographical location $\left(36\right.$ to $45^{\circ} \mathrm{N}$ ) and chronological control (at least two radiocarbon dates or dated tephra layers in the time span 6-2 ka) (Fig. 1). The vegetation dynamics of the selected pollen records during the time span 5-3 ka was examined, especially concerning changes in AP percentages and floristic composition, to establish whether any variation in forest cover occurred during the $4.2 \mathrm{ka}$ event. It should also be considered that pollen impressions of human actions can be sensibly different under different cultures: the Neolithic spread of agricultural systems would have only caused pollen signals producing fairly local effects (for example, the presence of cereal-type pollen grains), while the deforestation events of the subsequent cultural phases (e.g., Bronze Age) had regional echoes in pollen rain (Mercuri, 2014).

We arbitrarily considered a drop in AP of at least $10 \%$ as an event of forest decline, although we are aware that, due to the intrinsic properties of percentage calculations, this value may be indicative of vegetation changes of a quite different extent in different sites depending on the density of vegetation (Magri, 1994). Besides, pollen rain circulation can mask altitudinal displacements of vegetation in mountains and water-river transport may affect pollen representation in plain landscapes. This problem is especially relevant as we have selected pollen records from very diverse geographic situations (bogs, mountain lakes, crater lakes, coastal wetlands, lagoons, marine sediments, etc.). For this reason, we have shortly reported the main geographical features of each site.

A further methodological complication is the type and role of anthropological indicators used to detect the human impact on vegetation. In order to keep an independent view of the interpretation of pollen anthropological indicators, in the results we have carefully reported the interpretation provided in the original publication of each pollen record. This strategy limits the introduction of systematic errors due to our personal interpretation of palynological data and provides a mediated view of the interpretation of the palynological scientific community.

Pollen records for which pollen counts are not available to us have been digitized from the published pollen diagrams. Pollen diagrams in Fig. 2 were plotted using the program Psimpoll (Bennett, 2009).

\section{Results}

The main vegetation changes between $5 \mathrm{ka}$ and $3 \mathrm{ka}$, as recorded in the 36 selected pollen records, are shortly reported and discussed, following the numbering of sites in Fig. 1. The AP percentage diagrams of a selection of sites, representative of a range of environmental conditions, are represented in Fig. 2.

1. Mogge di Ertola (Fig. 2) is a small plateau lying at $1015 \mathrm{~m}$ about $25 \mathrm{~km}$ from the Ligurian coast (Guido et al., 2013). Mean annual precipitation is about $2000 \mathrm{~mm}$, with two rainfall peaks in November and March-April. The interval $5-3 \mathrm{ka}$ is characterized by the dominance of Abies accompanied by Fagus, deciduous Quercus, and Corylus. Unambiguous signals of local land use in the Mogge di Ertola pollen record only appear since ca. $2 \mathrm{ka}$, when the fir pollen curve decreases at the same time as an increase in microcharcoal particles, suggesting local burning activities.

2. Lago Riane is located at an altitude of $1279 \mathrm{~m}$ in the Ligurian Apennines (Branch, 2013). Mean annual precipitation is ca. $1600 \mathrm{~mm}$. The interval 5-3 ka shows highly forested conditions characterized by fluctuations of Abies and Fagus being alternately dominant. A fluctuating environment is also observed around 4.2 ka during the Early Bronze Age, which coincided in Liguria with a period of rapid climate change characterized by high summer precipitation. A temporary woodland expansion at ca. 3.9-3.6 ka was related to a reduction of human pressure on the environment, immediately preceding the development of agricultural terracing during the Middle Bronze Age.

3. Lago di Bargone is situated at $9 \mathrm{~km}$ from the Ligurian coast at $831 \mathrm{~m}$ a.s.l. (Cruise et al., 2009). Mean annual precipitation is around $1800 \mathrm{~mm}$. Between 5 and $3 \mathrm{ka}$ there is a progressive increase in the forest cover, mainly involving an expansion of Fagus, Quercus cerris, and Q. ilex communities. During the Bronze Age, the rise in arboreal frequencies suggests a general reduction of human exploitation. There is no evidence of forest decline at $4.2 \mathrm{ka}$.

4. Lago Padule (Fig. 2) lies at an altitude of $1187 \mathrm{~m}$ on the north-facing slopes of the Apennines close to the Passo del Cerreto (Watson, 1996). Mean annual precipitation is about $2000 \mathrm{~mm}$. The pollen record points to an Abiesdominated densely forested landscape, with increasing abundance of Fagus, to form a mixed Abies-Fagus complex. There is no evidence of forest decline at $4.2 \mathrm{ka}$.

5. Pavullo sul Frignano is a karstic former lake located at $675 \mathrm{~m}$ a.s.l. on the northern slope of the Tuscan-Emilian Apennines (Vescovi et al., 2010a). Mean annual precipitation is about $970 \mathrm{~mm}$. A marked change in the structure and composition of the vegetation, from an Abiesdominated forest to a mixed deciduous semi-open forest characterized by Quercus, Corylus, and Fagus, occurred between $6 \mathrm{ka}$ and $5 \mathrm{ka}$. After this turnover, the vegetational landscape did not substantially change in the interval 5-3 ka apart from a drop (15\%) in AP \% recorded 


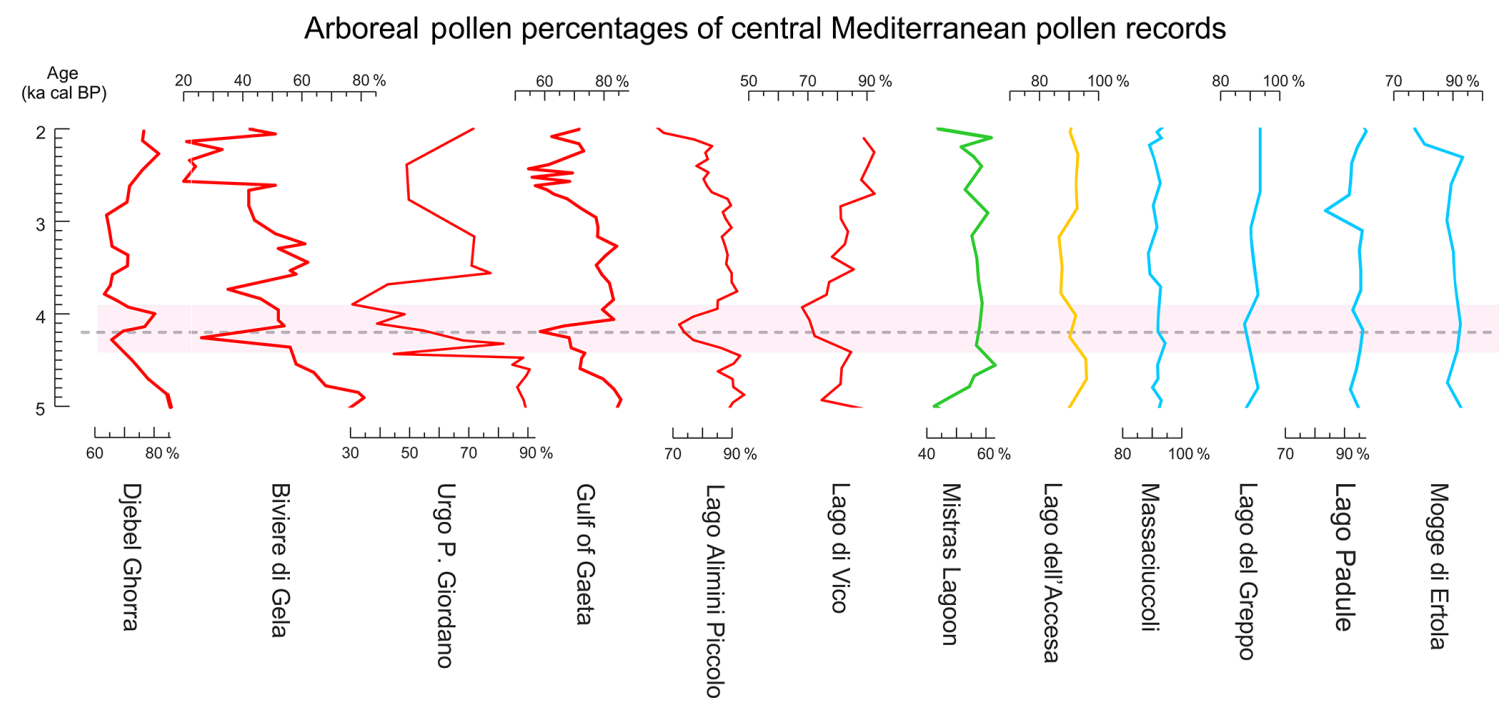

Figure 2. Arboreal pollen (AP) percentage diagrams of selected sites from the central Mediterranean. The dashed line and pink band represent the $4.2 \mathrm{ka}$ event. The following pollen records have been redrawn from the original publications: Biviere di Gela: Noti et al. (2009); Urgo Pietra Giordano: Tinner et al. (2016); Lago dell'Accesa: Drescher-Schenider et al. (2007); Lago di Massaciuccoli: Colombaroli et al. (2007); Lago del Greppo: Vescovi et al. (2010b); Lago Padule: Watson (1996); Mogge di Ertola: Guido et al. (2013). The record of Djebel Ghorra (Ben Tiba, 1995) was redrawn from Stambouli-Essassi et al. (2007). The records from the Gulf of Gaeta (Di Rita et al., 2018b), Lago Alimini Piccolo (Di Rita and Magri, 2009), Lago di Vico (Magri and Sadori, 1999), and Mistras Lagoon (Di Rita and Melis, 2013) were analyzed by the authors.

in a single sample around $3.6 \mathrm{ka}$. An increase in anthropogenic taxa (e.g., Juglans, cereals, Plantago, and Urtica) is recorded well after the main vegetation change around $4.5 \mathrm{ka}$. Charcoal-inferred regional fire activity peaked at around $4.2 \mathrm{ka}$, together with an increase in Cerealia type, while forest opening started at ca. $5 \mathrm{ka}$ and remained substantially unchanged until and after $4.2 \mathrm{ka}$.

6. Ospitale is a small bog close to the homonymous village at about $1225 \mathrm{~m}$ a.s.l. (Watson, 1996). Mean annual precipitation is about $1700 \mathrm{~mm}$. Between 5 and $3 \mathrm{ka}$, Abies dominates a fully forested environment. No change in forest cover is recorded at around $4.2 \mathrm{ka}$, except for a slight development of fir communities.

7. Lago del Greppo (Fig. 2) is a small and shallow pond located at $1442 \mathrm{~m}$ in the northern Apennines (Vescovi et al., 2010b). Mean annual precipitation is over $2500 \mathrm{~mm}$. Between 5 and $3 \mathrm{ka}$, the pollen record documents a densely forested environment (AP $>95 \%$ ) dominated by Abies and Fagus with significant frequencies of Picea (ca. 10\%). Despite a progressive decline in Abies, the forest remains very dense and almost stable until the present time.

8. Lago di Massaciuccoli (Fig. 2) is a coastal lake located in the Versilia Plain in northern Tuscany (Colombaroli et al., 2007). The mean annual precipitation is $910 \mathrm{~mm}$, most of which is concentrated in autumn and winter. Between 5 and $3 \mathrm{ka}$, the pollen record shows quite sta- ble conditions in the structure of the vegetation, outlining a densely forested environment. Trees and shrubs, ranging from $85 \%$ to $95 \%$, are dominated by Quercus communities rich in mesic elements such as $\mathrm{Fa}$ gus, Carpinus, Ostrya, and Abies. The main vegetational change is represented by an expansion of evergreen Quercus, which became the main woody taxon, accompanied by a slight increase in Ericaceae at around $4.4 \mathrm{ka}$. Direct evidence for human impact is weak, considering that primary and secondary human indicators like Plantago, Cerealia, Linum, Artemisia, and Asteroideae (Behre, 1981) do not show any significant trend. Charcoal-inferred regional fire activity was at a minimum at ca. $4.5-3 \mathrm{ka}$, with no signs of human activity.

9. Crovani is a coastal pond located in the northeastern side of Corsica (Reille, 1992). Mean annual precipitation is ca. $650 \mathrm{~mm}$. The vegetation history of the investigated period is characterized by open forest conditions up to $4.9 \mathrm{ka}$, with Erica arborea and evergreen oaks as dominant woody taxa, accompanied by a significant abundance of Alnus. At ca. $4.4 \mathrm{ka}$, an important opening of the landscape is recorded, mainly involving Quercus ilex and Erica arborea communities replaced by grasses and sedges. When vegetation recovers, after a few centuries, there is a new increase in evergreen elements, mostly represented by E. arborea. Scattered records of cereals represent the main pollen evidence of human activity between 5 and $3 \mathrm{ka}$. 
10. Lake Creno is a montane lake located at $1310 \mathrm{~m}$ in the center of the island of Corsica (Reille et al., 1999). Mean annual precipitation is ca. $1270 \mathrm{~mm}$. In the interval 5-3 ka there was a period of stability with a densely forested environment marked by the regional dominance of oak forest with Betula. A mixed maquis with Quercus ilex and Erica arborea, dominant at lower elevations, reached the lake altitude. There is no evidence of forest decline at $4.2 \mathrm{ka}$.

11. Aleria del Sale is a lagoon formed around 5500 years ago (Currás et al., 2017). Mean annual precipitation is ca. $650 \mathrm{~mm}$. Between 5 and $3 \mathrm{ka}$, the vegetation was characterized by deciduous and evergreen Quercus communities as dominant elements, accompanied by other woody taxa including Alnus, Pinus, Fagus, Corylus, and Betula. This floristic admixture probably reflects diverse environmental conditions at a regional scale. The main vegetation change is represented by a temporary decline in the main trees; Quercus reached a minimum at $4.45 \mathrm{ka}$, whereupon it significantly increased along with a progressive increase in $\mathrm{Er}$ ica arborea, while Pinus and Alnus reached a minimum around $4.2 \mathrm{ka}$, but subsequently they recovered to previous values. The lack of anthropogenic indicators such as cereal pollen and coprophilous fungal spores between 4.45 and $4.2 \mathrm{ka}$, suggesting absence of human activities, was interpreted as the main factor favoring an oak forest recovery.

12. Greco Pond is a coastal wetland located on Cavallo Island (Lavezzi archipelago; Corsica) (Poher et al., 2017). Mean annual precipitation is ca. $550 \mathrm{~mm}$. A change in the composition of the vegetation, from an Erica-dominated semi-open shrubland $(\mathrm{AP}=60 \%)$ to a mixed semi-open maquis mainly composed of evergreen and deciduous Quercus communities, occurred between $5.5 \mathrm{ka}$ and $5 \mathrm{ka}$. After this turnover, the vegetational landscape did not substantially change in the interval 5-3 ka, except for a clear increase in Quercus suber starting from $4.1 \mathrm{ka}$. Myrtus increased around $3.8 \mathrm{ka}$. No significant changes in forest cover are reported at $4.2 \mathrm{ka}$.

13. Lago dell'Accesa (Fig. 2) is a lake situated in the southern part of Tuscany about $12 \mathrm{~km}$ from the Tyrrhenian coast (Drescher-Schneider et al., 2007; Vannière et al., 2008). Mean annual precipitation is ca. $750 \mathrm{~mm}$. From 5 to $3 \mathrm{ka}$, the vegetation surrounding Lago dell'Accesa was a mixed forest dominated by evergreen and deciduous Quercus communities. Slight AP percentage oscillations are recorded around $4.2 \mathrm{ka}$, when a marked decline in mediterranean trees and shrubs was paralleled by an increase in deciduous oaks. After $4.3 \mathrm{ka}$, most anthropogenic indicators start to be recorded in continuous curves; cultivation of cereals and pasture activities are recorded. There is also an increase in fire frequency as recorded by microcharcoal, culminating around $3.4 \mathrm{ka}$.

14. Lagaccione is an artificially dried-out maar lake close to Bolsena Lake in central Italy at $355 \mathrm{~m}$ a.s.1. (Magri, 1999). Mean annual precipitation is ca. $1030 \mathrm{~mm}$. The pollen record lacks the last 3700 years. At $5 \mathrm{ka}$, the pollen record depicts a densely forested landscape dominated by deciduous oaks accompanied by Fagus, Corylus, and evergreen oaks, together with many other tree taxa. A clear reduction $(-15 \%)$ in AP percentages, culminating at $4.2 \mathrm{ka}$, points to a forest decline, mostly related to a decline in Fagus. At the same time there is a slight increase in cereal pollen. After $4.2 \mathrm{ka}$, trees partially recovered.

15. Lago di Vico (Fig. 2) is a maar lake located at $510 \mathrm{~m}$ in the northern Lazio region (Magri and Sadori, 1999). Mean annual precipitation is ca. $1050 \mathrm{~mm}$. Between 5 and $3 \mathrm{ka}$, the vegetation was dominated by deciduous oaks accompanied by many evergreen and deciduous elements, composing a floristically diverse forested environment. A temporary forest decline $(-15 \%$ AP), associated with evidence for agricultural activity (e.g., cereals), was recorded between 4.3 and $3.6 \mathrm{ka}$. During this event, single grains of Cedrus pollen are recorded, pointing to an African origin of dominant winds (Magri and Parra, 2002). Anthropogenic indicators disappear after $3.6 \mathrm{ka}$, when a pronounced recovery of trees, notably deciduous Quercus, is recorded.

16. Lingua D'Oca-Interporto refers to a pollen record obtained from the former Stagno di Maccarese, a shallowwater pond located in the northern sector of the Tiber mouth channel (Di Rita et al., 2010). Mean annual precipitation is ca. $740 \mathrm{~mm}$. Between 5 and $3 \mathrm{ka}$, the site was characterized by the development of extensive Alnus-dominated floodplain forest formations rich in Salix and Fraxinus stands. This vegetation is the result of complex environmental dynamics triggered by a decrease in the rate of sea level rise that determined deep geomorphic and sedimentological changes in the river floodplains, consistent with coastal barrier accumulation, lagoon habitat formations, river mouth modifications, and peat deposition, among others (Di Rita et al., 2015). The nearby Bronze Age settlements of Le Marrucole and Le Pagliete did not produce a clear impact on the vegetational landscape (Di Rita et al., 2012). No significant changes in forest cover are reported at $4.2 \mathrm{ka}$, which may have been masked by local hydrological dynamics.

17. Core RF93-30 was drilled in the central Adriatic Sea $18 \mathrm{~km}$ north of the northern coast of the Gargano promontory at a water depth of $77 \mathrm{~m}$ (Oldfield et al., 2003; Mercuri et al., 2012). Mean annual precipitation 
along the nearest coast is ca. $700 \mathrm{~mm}$. Around $5 \mathrm{ka}$, widespread forest vegetation was dominated by deciduous and evergreen Quercus, Abies, and Fagus. A drop in Quercus ilex type around $4.13 \mathrm{ka}$ is contemporary with a rise of deciduous oaks and a decline in Abies. According to Mercuri et al. (2012), the decrease in Abies may be a result of the clearance of silver fir preceding the clearance of oaks produced by human action after a climate change became established. According to the chronological settings proposed by Oldfield et al. (2003) and Mercuri et al. (2012) a clear drop in AP (-25\%) occurs starting around $3.9 \mathrm{ka}$.

18. Lago Battaglia is a dried-out coastal lake on the northeastern margin of the Gargano headland (Caroli and Caldara, 2007). Mean annual precipitation in the area is between 550 and $650 \mathrm{~mm}$. From 5 to $4.2 \mathrm{ka}$, the landscape was characterized by mediterranean evergreen vegetation along the coastline and mixed deciduous forests at higher elevations. Around $4.2 \mathrm{ka}$ a temporary decrease in the arboreal vegetation, mainly involving broad-leaved trees and Pinus, was interpreted as the result of a climate change towards drier conditions. Between 3.5 and $3 \mathrm{ka}$ the forest vegetation recovered with a remarkable expansion of Pinus, probably P. halepensis, which is a main element of the present landscape in the northern sector of the Gargano headland. Although scattered anthropogenic indicators (e.g., cereals, Castanea, and Vitis) are present all along the sequence, significant human impact on the natural vegetation seems to have occurred since about $2.7 \mathrm{ka}$.

19. Lago Salso is a former coastal lake produced by hydrological and geomorphological changes that occurred in the extinct Salpi Lagoon (Apulia region, Italy) (Di Rita et al., 2011). The mean annual precipitation is ca. $460 \mathrm{~mm}$. Between 5 and $4.05 \mathrm{ka}$ the landscape was characterized by a salt marsh dominated by Salicornia s.l. and Ruppia, probably surrounded by evergreen scrubland mainly composed of Olea, Pistacia, and Phillyrea, while extensive broad-leaved forests were located at higher elevations inland. Major fluctuations of the salt marsh vegetation, related to changes in the extent of the Salpi Lagoon, were possibly modulated by solar activity (Di Rita, 2013). Between 4.05 and $3.8 \mathrm{ka}$, marked environmental transformations occurred at a regional scale, with an abrupt opening of the forest involving almost all the broad-leaved trees. After $3.8 \mathrm{ka}$ the pollen record is interrupted. However, paleovegetational information for the interval $3.5-3.2 \mathrm{ka}$ is provided by another core (C5) from the same area, depicting an open landscape. Anthropogenic pollen indicators are continuously recorded, consistently with a long-term occupation of the area, since the early Neolithic.
20. Lago Grande di Monticchio is a maar lake located in the Basilicata region at an elevation of $656 \mathrm{~m}$ (Allen et al., 2002). Mean annual precipitation is ca. $800 \mathrm{~mm}$. Between 5 and $3 \mathrm{ka}$, the pollen record points to a densely forested landscape dominated by deciduous Quercus, showing a decreasing trend in this interval. Other important trees were Alnus, Ostrya, Carpinus, Ulmus, Quercus ilex, Fagus, and Abies and Taxus among the conifers. At around $4.2 \mathrm{ka}$ a slight decrease in AP is recorded $(-5 \%)$, just before a gap in the pollen record from 4 to $3.5 \mathrm{ka}$. Despite the fact that cereal-type pollen is present all along the record, no vegetation change is unambiguously attributed to human impact by the authors.

21. Lago Patria is a brackish lagoon connected to the Gulf of Gaeta (Tyrrhenian Sea) through a narrow channel (Di Rita et al., 2018c). Mean annual precipitation is about $800 \mathrm{~m}$. The interval 5-3 ka was characterized by mixed deciduous and evergreen oak-dominated forests, rich in both xeric (e.g., evergreen Quercus, Pistacia, and Ericaceae) and mesic woody taxa (deciduous Quercus, Carpinus betulus, and Fagus). A forest decline is recorded around $4.2 \mathrm{ka}$, especially involving broadleaved trees $(-24 \%)$ and corresponding to a temporary decrease in human impact. This event was followed, between 3.9 and $3.3 \mathrm{ka}$, by a forest recovery with a remarkable development of mesic trees, notably Fagus, influenced by wet climate conditions. While human settlements are missing from this coastal area between 5 and $3 \mathrm{ka}$, which suggests a marginal role of human activity in determining landscape changes, there is a continuous presence of anthropogenic pollen indicators in the pollen record, which stimulates new archeological investigations.

22. The Gulf of Gaeta (Fig. 2) is a marine pollen record from a core recovered at a distance of $15 \mathrm{~km}$ from the Campanian coast (central Tyrrhenian Sea) at $93 \mathrm{~m}$ below sea level (Margaritelli et al., 2016; Di Rita et al., 2018b). Mean annual precipitation along the coast is about $850 \mathrm{~mm}$. From 5 to $4.75 \mathrm{ka}$ a dense forest was composed of mixed temperate and mediterranean forests dominated by deciduous and evergreen Quercus. From 4.75 to $4.1 \mathrm{ka}$, a forest decline, culminating at around $4.2 \mathrm{ka}$, was mainly related to a decrease in evergreen Quercus. High amounts of Cichorioideae characterize this open environment. Anthropogenic pollen taxa, including Olea, Vitis, Castanea, and Carduus, show only sporadic occurrences. From 4.1 to $3 \mathrm{ka}$, a new forest development shows a remarkable increase in evergreen and deciduous elements (mainly Quercus, Ostrya-Carpinus orientalis, and Fagus) at the same time as a modest increase in anthropogenic indicators. The difference in AP percentages between $5 \mathrm{ka}$ and $4.2 \mathrm{ka}$ is over $25 \%$. 
23. Stagno di Sa Curcurica is a small coastal salty lake located in northeastern Sardinia in the province of Nuoro (Beffa et al., 2016). Mean annual precipitation is ca. $560 \mathrm{~mm}$. A change in the composition of the vegetation, from an Erica-dominated maquis to a mixed maquis in which Erica is accompanied by evergreen Quercus communities, occurred between 6 and $5 \mathrm{ka}$. After this turnover, the vegetational landscape did not substantially change in the interval 5-3 ka. No significant changes are recorded in either herbaceous taxa or pollen indicative of land use (e.g., Plantago lanceolata type, Rumex acetosella type, and Cerealia type) between 5 and $3 \mathrm{ka}$, but a charcoal-inferred increase in regional fire activity is recorded around $4.5 \mathrm{ka}$.

24. Mistras Lagoon (Fig. 2) is a brackish lagoon in the central-western part of the Sardinia channel (Di Rita and Melis, 2013). Mean annual precipitation is ca. $560 \mathrm{~mm}$. Up to $4.6 \mathrm{ka}$, the vegetation of the site was characterized by a local Chenopodiaceae-Amaranthaceae-dominated salt marsh bordered by Pistacia scrubland formations, while in the hilly and montane sectors there were mixed oak woodlands. Between 4.6 and $4 \mathrm{ka}$, the area experienced significant environmental changes related to a rapid salt marsh decline, caused by local hydrological and sedimentological dynamics, and a general increase in sclerophyllous communities, especially holm oaks, paralleled by a decline in both cork and deciduous oaks. Rather stable vegetation conditions marked the period between 4 and $3 \mathrm{ka}$, which corresponds to the phase of maximum human frequentation of the area, characterized by the development of the Nuragic civilization, which was devoted to cereal cultivation and grape management.

25. Lago Trifoglietti (1048 $\mathrm{m}$ a.s.l.) is part of a natural highaltitude lacustrine system located in the Calabria region (Joannin et al., 2012). The closest meteorological station indicates a mean annual precipitation of $1850 \mathrm{~mm}$. A densely forested landscape, featured by high percentages of mountain trees Abies and Fagus, was punctuated by a decline in trees between ca. 4.9 and $4.65 \mathrm{ka}$. However, a pollen-based water-depth reconstruction points to relatively deep water conditions favoring the development of an Alnus carr, interpreted as the establishment of a wet climate. The interval 3.5-2.5 ka, characterized by a new forest decline, was also interpreted as a humid phase due to high water-depth evidence and a new rise in Alnus. By contrast, the interval 4.65-3.5 ka, interpreted as a shallow-water phase related to increased aridity, corresponds to a period of general forest development. In addition, the authors refer to a dry episode that was particularly intense from 4 to $3.6 \mathrm{ka}$, according to the water-depth record, and around $4.2 \mathrm{ka}$, according to the reconstructed annual precipitation record, which appears to be associated with a temporary decline in both AP $(-15 \%)$ and the main trees (Fagus, Abies, Ostrya, and Quercus deciduous) starting from $4 \mathrm{ka}$. The pollen record of Trifoglietti shows only poor imprints of agricultural activity and anthropogenic indicators. The strongest evidence of human impact in the surroundings of the site is considered the selective exploitation of fir, especially after $4 \mathrm{ka}$.

26. Lago Alimini Piccolo (Fig. 2) is a tectonic coastal lake located in the southeastern part of the Salento Peninsula (Di Rita and Magri, 2009). Mean annual precipitation is ca. $700 \mathrm{~mm}$. Between 5 and $4.35 \mathrm{ka}$, the landscape was covered by dense oak-dominated mediterranean evergreen vegetation with Pistacia, Olea, Phillyrea, and Ericaceae. Between 4.35 and $3.9 \mathrm{ka}$, the Alimini area experienced a distinct opening of the forest, particularly affecting evergreen oaks, with a complete absence of both cereal pollen and other primary anthropogenic indicators. Between 3.9 and $3 \mathrm{ka}$, a new forest expansion was characterized by a remarkable increase in evergreen elements, including mediterranean oaks. Afterwards, the forest cover shows a steady and moderate depletion through time, which might be due to a progressive increase in human activities during the Bronze Age, culminating in a remarkable increase in Olea at around $3.2 \mathrm{ka}$, consistent with the management of olive resources by local populations.

27. Urio Quattrocchi is a small lake $(0.5 \mathrm{ha})$ located at 1044 m a.s.l. in the western Nebrodi Mountains (northern Sicily) about $13 \mathrm{~km}$ from the Tyrrhenian Sea (Bisculm et al., 2012). Mean annual precipitation is ca. $990 \mathrm{~mm}$. Between 5 and $3 \mathrm{ka}$, the pollen record shows a first phase characterized by a dramatic forest opening culminating at ca. $4.7 \mathrm{ka}$ with a minimum in AP $(20 \%)$, mostly reflecting a drop in deciduous and evergreen Quercus. According to the authors, crop and weed taxa such as Cerealia, Cichorioideae, Plantago, Asteroideae, and Rumex, together with high charcoal influx at 5.0-4.5 ka, suggest that human activities and anthropogenic fire may have caused the forest decline. This vegetation change was followed by significant recovery of the woody taxa, which were fully restored at ca. $3.4 \mathrm{ka}(\mathrm{AP}>80 \%)$, and favored by a remarkable expansion of oaks (Quercus cerris-suber $>60 \%$ ) accompanied by the development of Fagus communities.

28. Urgo Pietra Giordano (Fig. 2) is a small lake located at $1323 \mathrm{~m}$ a.s.l. in the Madonie Mountains (northern Sicily) (Tinner et al., 2016). Mean annual precipitation is around $900 \mathrm{~mm}$. Between 5 and $4.7 \mathrm{ka}$, Fagus sylvatica dominated the densely forested environment, together with Ilex aquifolium, forming beech-holly mesophilous forest. Deciduous oaks were also abundant in this interval. Beech-holly forests declined at the onset of the Bronze Age at 4.5-4.15 ka and were massively 
destroyed due to burning at 4.15-3.65 ka, when all the dominant trees show a minimum. Microcharcoal shows a first peak around $4.5 \mathrm{ka}$ and a second peak after $3.9 \mathrm{ka}$, but has very low values around $4.2 \mathrm{ka}$. After $3.65 \mathrm{ka}$ the forest experienced a new rapid recovery, especially favoring beech and oaks, while holly almost completely disappeared.

29. Lago di Pergusa is located in the central part of Sicily at an elevation of $667 \mathrm{~m}$ (Sadori and Narcisi, 2001). Mean annual precipitation is around $650 \mathrm{~mm}$. At $5 \mathrm{ka}$ the vegetation was dominated by deciduous Quercus, with $Q$. ilex, Olea, and Ulmus also abundant. A clear drop in AP concentration and percentages is found around $4.45 \mathrm{ka}$, along with an increase in floristic richness. Deciduous trees show a moderate decline followed by a rapid recovery around $4.1 \mathrm{ka}$. Evergreen oaks together with Olea show a significant increase only around $3.5 \mathrm{ka}$.

Biviere di Gela (Fig. 2) is a coastal lake in southeast Sicily (Noti et al., 2009). Mean annual precipitation is ca. $400 \mathrm{~mm}$. Evergreen forests and scrublands composed of $Q$. ilex, Olea, and Pistacia dominated the landscape until ca. $5 \mathrm{ka}$, after which time they declined in response to human impact, which was probably exacerbated by a general trend towards a dry climate. A partial shift towards Pistacia-dominated shrublands was probably a direct consequence of intense agricultural and pastoral activity, suggested by an increase in Cichorioideae, Brassicaceae, Rumex acetosella, and Sporormiella. A major reduction of the evergreen vegetation cover was recorded between 4.5 and 3.7 , with a minimum at $4.2 \mathrm{ka}$, in correspondence with a strong increase in anthropogenic indicators such as Plantago lanceolata type and charcoal-inferred regional fire activity, and was followed by a recovery between 3.7 and $2.6 \mathrm{ka}$ contemporarily with a slight reduction of human impact.

30. Gorgo Basso is a small lake of karstic origin located in southwestern Sicily ca. $2.2 \mathrm{~km}$ from the sea (Tinner et al., 2009). Mean annual precipitation is ca. $450 \mathrm{~mm}$. Between 5 and $3 \mathrm{ka}$, the landscape was characterized by a dense evergreen Olea-Quercus ilex forest. This interval was punctuated by a major event of evergreen cover reduction at 4.5-3.7 ka, corresponding to an increase in cereals, Plantago lanceolata, and charcoal particle influx. During this time interval, indicators of paleosalinity at Gorgo Basso suggest freshwater conditions, differently from the nearby Lago Preola, where admixing of seawater may explain a reconstructed salinity $>10000 \mathrm{mg} \mathrm{L}^{-1}$ (Curry et al., 2016).

31. Lago Preola is a medium-sized lake of ca. 33 ha located approx. $2 \mathrm{~km}$ from Gorgo Basso (Calò et al., 2012). Mean annual precipitation is ca. $450 \mathrm{~mm}$. Between 5 and $3 \mathrm{ka}$, Pistacia scrublands dominated the landscape together with Quercus ilex and Olea communities. The arboreal vegetation shows a fluctuating trend with a drop in Quercus ilex around $4.2 \mathrm{ka}$, which was replaced by Pistacia scrublands. Human disturbance, which started during the Neolithic at around $7.5 \mathrm{ka}$ and contributed to reducing the evergreen forest in favor of Pistacia scrubland, intensified from 2.6 to $2.2 \mathrm{ka}$, determining a progressive opening of the landscape.

32. Majen El Orbi is a peatland located at $200 \mathrm{ma}$ a.s.l. in reliefs facing the northwestern coast of Tunisia (Stambouli-Essassi et al., 2007). Mean annual precipitation is ca. $1200 \mathrm{~mm}$. Between 5 and $3 \mathrm{ka}$, the landscape was characterized by an admixture of deciduous and evergreen forest communities dominated by Quercus canariensis, $Q$. suber, and Erica arborea, with high amounts of other sclerophyllous trees, notably $Q$. coccifera and Myrtus communis. The main change in forest cover occurred around $4.5 \mathrm{ka}$ and featured a dramatic decline in $Q$. canariensis populations, an overall decrease in woody taxa, and a contemporary remarkable development of Apiaceae, accompanied by high amounts Poaceae related to arid climate conditions. After this event the forest cover started recovering around 4.2 ka with E. arborea, M. communis, and $Q$. coccifera shrubland, followed by a complete recovery of the $Q$. canariensis forest.

33. Majen Ben H'mida is a peatland located at $330 \mathrm{~m}$ a.s.l. in the massif of Djebel Chitane (Stambouli-Essassi et al., 2007). Mean annual precipitation is ca. $1400 \mathrm{~mm}$. Between 5 and $3 \mathrm{ka}$, the vegetation of the site was characterized by $Q$. canariensis, E. arborea, and $Q$. suber, the latter increasing after $4.5 \mathrm{ka}$. A major vegetation change occurred around $4 \mathrm{ka}$, determining the drop in the main woody taxa related to a climate change towards arid conditions, possibly exacerbated by the impact of human activities.

34. Dar Fatma is a peatland located at $780 \mathrm{~m}$ a.s.1. in the northwestern side of Tunisia (Stambouli-Essassi et al., 2007). Mean annual precipitation is around $1200 \mathrm{~mm}$. Between 5 and $3 \mathrm{ka}$, the pollen record from Dar Fatma I shows a semi-open landscape dominated by Poaceae. The forest vegetation was characterized by stands of $Q$. suber and E. arborea, showing a remarkable decline around $4.85 \mathrm{ka}$. This process corresponds to a biodiversity increase in herbaceous taxa and the contemporary first occurrence of cereals, suggesting a role of human impact in the vegetation change.

35. Djebel Ghorra (Fig. 2) is a peatland located at 1203 m a.s.1. in Tunisia (Ben Tiba, 1995; StambouliEssassi et al., 2007). Mean annual precipitation is ca. $1100 \mathrm{~mm}$. The interval 5-3 ka shows a landscape dominated by $Q$. canariensis accompanied by other 
4.2 ka BP event in the central Mediterranean

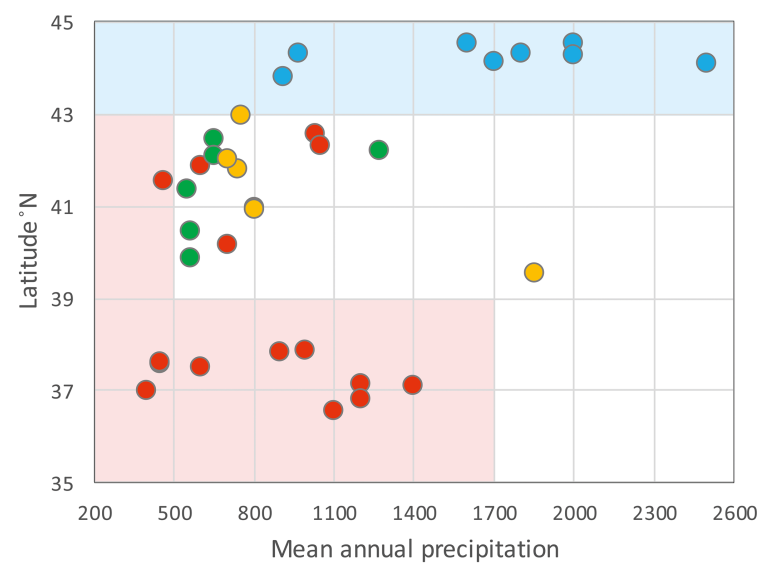

- Forest decline $\bullet$ No forest decline Sardinia-Corsica O Change uncertain

Figure 3. The latitude of the pollen records from the central Mediterranean is plotted against the respective mean annual precipitation. Red dots represent the pollen sites where a deforestation is clear during the $4.2 \mathrm{ka}$ event, and blue dots represent sites where there is no deforestation at $4.2 \mathrm{ka}$; green dots represent sites from Corsica and Sardinia, where there is a compositional change in vegetation, but no overall deforestation; yellow dots represent sites showing unclear vegetation changes around $4.2 \mathrm{ka}$.

woody taxa forming woodland and shrubland communities (e.g., Q. ilex, $Q$. suber, and E. arborea). Forest conditions marked by particularly high amounts of Q. canariensis ( $>70 \%$ ) were recorded, especially until $4.9 \mathrm{ka}$. Afterwards, the site experienced a rapid forest decline culminating at $4.3 \mathrm{ka}$, matched by a development of Poaceae. After a temporary forest recovery at $3.9 \mathrm{ka}$, the site was marked by a new vegetation opening and widespread grassland formations.

\section{Discussion}

The vegetation dynamics in the central Mediterranean during the $4.2 \mathrm{ka}$ event, as depicted by pollen records, is rather diverse, as it ranges from cases in which no clear change is observed to dramatic openings of the forest (Fig. 2). Considering the geographical location of the sites and their water availability, it is possible to distinguish four main situations (Figs. 1-3).

\section{Sites with no forest decline or vegetation change around} $4.2 \mathrm{ka}$. All the sites located north of $43^{\circ} \mathrm{N}$ show no significant variation in forest cover and composition (blue records in Figs. 1-3). They include mountain sites with mean annual precipitation $>2000 \mathrm{~mm}$ (e.g., Lago del Greppo, Lago Padule, Mogge di Ertola), as well as hilly or coastal sites with mean annual precipitation $<1000$ mm (e.g., Pavullo nel Frignano, Lago di Mas- saciuccoli). In most of these records, a slight and progressive increase in Fagus at the expense of Abies is observed before and during the $4.2 \mathrm{ka}$ event. At Lago di Massaciuccoli there was an expansion of evergreen Quercus. Considering the diversity of vegetation composition and mean annual precipitation values for these sites, it appears that a possible common factor determining no vegetation change at $4.2 \mathrm{ka}$ is the location north of $43^{\circ} \mathrm{N}$. At this latitude in the central Mediterranean, the prevalent climate mode has a North Atlantic influence. The NAO oscillation, besides conveying most of the storm tracks through the North Atlantic westerlies, strongly influences the northern Mediterranean cyclogenesis (e.g., Gulf of Genoa cyclogenesis) (Trigo et al., 2002), which pushes winter humid winds into the northern sectors of the central Mediterranean where they discharge precipitation once they are blocked by the reliefs of the Apennines and Alps. Negative NAO circulation phases in the north-central Mediterranean would determine a positive precipitation anomaly (Trigo et al., 2004), as in most of central Europe and the southwestern Mediterranean regions (Zielhofer et al., 2017; Di Rita et al., 2018a), also experienced during Bond events (Martín-Puertas et al., 2008; Trouet et al., 2009; Olsen et al., 2012). The $4.2 \mathrm{ka}$ climate event, corresponding to Bond event 3 and to a rapid inversion of the NAO index towards negative values between 4.3 and $4.2 \mathrm{ka}$ (Olsen et al., 2012), is expected to have produced more humid climate conditions in the north-central Mediterranean and in the southwestern Mediterranean (Zielhofer et al., 2018). However, the limit between wetter and drier zones is not clear-cut, being complicated by a possible nonstationary spatial relationship between NAO and precipitation over Europe (Pinto et al., 2007; VicenteSerrano and López-Moreno, 2008; López-Moreno et al., 2011). The speleothem records over the Apuan Alps (Renella and Corchia Cave) show consistent evidence of reduced cave recharge in a period ranging from ca. 4.5 to $3.8 \mathrm{ka}$ (Isola et al., 2019; Bini et al., 2018). These results imply a reduction of cyclones originating in the North Atlantic and of cyclogenetic activity in the Gulf of Genoa, pointing to a scenario of lower mean annual temperature, reduced precipitation during winter, and cooler and wetter summer conditions (Isola et al., 2019). A possible explanation to reconcile this paleoclimate evidence with pollen results in relation to the $4.2 \mathrm{ka}$ event is that a general decrease in precipitation in the very humid area of the northern Apennines (up to $2500 \mathrm{~mm} \mathrm{yr}^{-1}$ ) was sufficient to determine a change in the speleothem record, but not in the vegetation. Besides, wetter summer conditions are consistent with the development of a beech forest, as shown by the montane pollen sites of the northern Apennines (Branch, 2013). The different sensitivity of pollen and 
other proxy records may help to better define the geographical area influenced by the $4.2 \mathrm{ka}$ event.

2. Sites with a clear opening of forests around $4.2 \mathrm{ka}$. Several sites from central Italy at latitudes $<43^{\circ} \mathrm{N}$ and all the sites located at latitudes $<39^{\circ} \mathrm{N}$ show drops of over $10 \%$ in AP percentages (red records in Figs. 1-3). Their elevations range from sea level to over $1300 \mathrm{~m}$ a.s.l. and mean annual precipitation values range from 400 to $1400 \mathrm{~mm}$ (Fig. 3). The vegetation composition of these sites is very diverse, as it is characterized by mixed oak forests with a significant amount of Fagus at sites from central Italy (Lagaccione and Lago di Vico), mixed deciduous and evergreen oak-dominated forests in Tyrrhenian southern Italy (Gulf of Gaeta and Lago Patria), evergreen scrubland, mainly composed of evergreen oaks, Olea and Pistacia, or Pinus in Apulia (Lago Battaglia, Lago Salso, and Lago Alimini Piccolo), deciduous oakdominated forests in central-northern Sicily (Urio Quattrocchi, Urgo Pietra Giordano, and Lago di Pergusa), scrublands mainly composed of Q. ilex, Olea, and Pistacia in coastal sites of southern Sicily (Biviere di Gela, Gorgo Basso, and Lago Preola), and admixtures of deciduous and evergreen forest communities dominated by $Q$. canariensis, $Q$. suber, and $E$. arborea in northern Tunisia (Majen El Orbi, Majen Ben H'mida, and Dar Fatma). At these sites, independently of altitude and vegetation composition, AP percentages drop around 4.4-4.3 ka, reach a minimum around $4.2 \mathrm{ka}$ and progressively recover. At all sites, the recovery process is complete by $3.6 \mathrm{ka}$. There are, however, some differences among sites in the timing, duration, and intensity of the vegetation change. The forest decline is earlier in the Tunisian and Sicilian sites, followed by the sites in southern Italy, and then in central Italy (Fig. 2). The time interval characterized by open vegetation appears longer in Sicily than in peninsular Italy (Fig. 2). Although these differences may be partly due to unprecise dating of the records, a general delay in the more northern sites is visible. Considering the progressive geographical pattern of the opening of forests in the central Mediterranean, which is coeval to the 4.2 ka climate event documented in many Mediterranean sites, we suggest that it may be explained by a progressive northward displacement of the north African high-pressure cell, conveying arid air masses and inducing torrid temperatures in the central Mediterranean in a way similar to the modern heat waves moving from Africa (Di Rita and Magri, 2009; Di Rita et al., 2018b). The frequent reiteration and persistence of such conditions around $4.2 \mathrm{ka}$ may have severely affected the southern regions of the central Mediterranean (up to $39^{\circ} \mathrm{N}$ ) and also partly influenced central Italy (up to $43^{\circ} \mathrm{N}$ ). Similarly, the intensity of the opening of the forest was generally stronger at the southern sites than at the sites located at latitudes $>39^{\circ} \mathrm{N}$ (Fig. 2). This difference cannot be simply ascribed to precipitation, elevation, and vegetation composition at the studied sites. For example, the Sicilian sites where the forest decline was always very marked have at present mean annual precipitation ranging from 400 to $1000 \mathrm{~mm}$ and elevations from sea level to over $1300 \mathrm{~m}$; they are characterized by a variety of vegetation types ranging from mediterranean scrubland to beech forest. Instead, a relation may be found between the intensity of forest decline and latitude, as all the sites where AP dropped at $4.2 \mathrm{ka}$ are located south of $43^{\circ} \mathrm{N}$, and all the sites south of $39^{\circ} \mathrm{N}$ show a clear forest decline (Fig. 3). Although the opening of forests coeval to the $4.2 \mathrm{ka}$ event is especially visible in the southern regions, all sites south of $43^{\circ} \mathrm{N}$ with mean annual precipitation $<500 \mathrm{~mm}$ are affected by this event (Fig. 3). This suggests that the environments suffering from water deficit may be particularly vulnerable to the climatic regime induced by a displacement of the north African high-pressure cell to undergo a general forest decline. A further factor that may have influenced the vegetation of the southern regions in the central Mediterranean is an extensive and intense human impact on the landscape documented by archeological sites, anthropogenic indicators in pollen records, and rich archeobotanical evidence (Mariotti Lippi et al., 2018; http://brainplants. successoterra.net/, last access: 8 January 2019). While widespread human presence in the Early Bronze Age is attested in all of Italy, values for anthropogenic pollen indicators are higher in southern Italy and Sicily than elsewhere, indicating that human activity was particularly intense during these events of forest decline. One possible explanation for the increased presence of anthropogenic indicators at the same time as a forest decline in response to a climate change towards aridity is that a dry event may have spurred the expansion of agriculture and the diffusion of human settlements in southern Italy and Sicily by thinning the woodland, thereby aiding its clearance by farmers (Magri, 1995; Yll et al., 1997; Lawson et al., 2004). Archeological evidence indicates that the beginning of the Neolithic era occurred earlier in dry areas of Sicily and southern Italy (Natali and Forgia, 2018) than in comparatively wetter areas of central and northern Italy (Radi and Petrinelli Pannocchia, 2018). In addition, ecosystems and vegetation were less resilient and more vulnerable to human disturbance with increasing heat and drought along a northsouth gradient. This is also consistent with the evidence that after $4.2 \mathrm{ka}$ a new progressive change towards more humid conditions favored the recovery of forest vegetation, independently of the widespread presence of human communities. In this case, human activity was not able to hinder the new diffusion of forests that expanded everywhere in the south-central Mediterranean after the 4.2 ka event. 
3. Sites with an unclear vegetation change around $4.2 \mathrm{ka}$. We include in this category some sites of central and southern Italy (latitude between 39 and $43^{\circ} \mathrm{N}$ ) with compositional variations in vegetation but no clear drop in AP percentages around $4.2 \mathrm{ka}$, as well as some doubtful cases that we will shortly discuss. These sites are represented in yellow in Figs. 1-3. We do not include in this list Lake Preola, where a clear drop in trees peaking around $4.2 \mathrm{ka}$ is compensated for by a shrubland (Calò et al., 2012). By contrast, we include Lago dell' Accesa, where a drop in evergreen oaks around $4.2 \mathrm{ka}$ is compensated for by deciduous oaks, which contribute to maintaining forested conditions in spite of a significant compositional change in vegetation (DrescherSchneider et al., 2007; Vannière et al., 2008). At Lingua d'Oca-Interporto, the proximity of the Tiber River and the Tyrrhenian Sea caused repeated floods and the ingress of marine water, which severely affected the record of vegetation dynamics in the hills behind the large coastal wetland, making it difficult to recognize any vegetation change in response to climate events (Di Rita et al., 2015). The Adriatic core RF93-30, which shows a clear drop in AP starting only around $3.9 \mathrm{ka}$, collects pollen from the Po Valley and north-central Apennines, and only in part from the central and southern Italian Peninsula, in spite of its location just north of the Gargano Promontory (Mercuri et al., 2012). At Lago Grande di Monticchio, a slight decrease in AP is recorded $(-5 \%)$ just before a gap in the pollen record from 4 to $3.5 \mathrm{ka}$ (Allen et al., 2002) that may have contributed to masking the $4.2 \mathrm{ka}$ event. At Lago Trifoglietti, the authors report an intense dry episode around 4.2 ka shown by the reconstructed annual precipitation record, which is not visible in the pollen record (Joannin et al., 2012). One possible explanation for this discrepancy is that in this mountain area a high mean annual precipitation (ca. $1850 \mathrm{~mm}$ ) favors the development of a dense forest, so even a marked decrease in moisture conditions may not provoke any severe decline in forest cover. On the whole, in these "uncertain sites" different factors may have contributed to partially masking a forest decline.

4. Pollen records from Corsica and Sardinia. Except for the coastal site of Crovani, where $Q$. ilex and E. arborea communities were replaced by grasses and sedges around $4.4 \mathrm{ka}$, no significant change is visible around $4.2 \mathrm{ka}$. The vegetational dynamics of these islands are quite different from central and southern Italy, although these regions are located at the same latitude and have similar mean annual precipitation values. For this reason, the Sardinian-Corsican pollen records have been separated into a different group marked in green in Figs. 1-3. They are from both coastal (Crovani, Aleria del Sale, Greco Pond, Sa Curcurica, and Mistras La- goon) and inland (Lake Creno) sites representing different vegetation types. The different dynamics of forest vegetation compared to the Italian Peninsula suggest that the two regions may be subject to different prevalent air mass circulation, Sardinia and Corsica not being substantially affected by the north African climate system. However, the pollen records from Mistras and Sa Curcurica, showing pollen from Betula of northern origin before and after but not during the $4.2 \mathrm{ka}$ event, suggests that an attenuation of the North Atlantic influence occurred at this time, without determining any significant forest decline.

\section{Conclusions}

The examination of pollen records from the central Mediterranean regions in the time interval around $4.2 \mathrm{ka}$ has allowed for the recognition of vegetation dynamics reflecting a geographical pattern related to latitude and precipitation regime.

We have found that sites located between 43 and $45^{\circ} \mathrm{N}$ show no significant vegetation change in correspondence with the $4.2 \mathrm{ka}$ event, independently of latitude, elevation, and forest composition. In these regions, it is likely that the $4.2 \mathrm{ka}$ event either produced only a modest decrease in precipitation not sufficient to determine a forest decline or produced a winter decrease and a summer increase in precipitation, as suggested by Isola et al. (2019), favoring the development of mountain forests.

Several sites located on the Italian Peninsula between 39 and $43^{\circ} \mathrm{N}$ show a marked forest decline, suggesting that a lowering of rainfall occurred that was sufficiently strong to determine a vegetation change. However, in some sites this pattern is not clear, as it determined only changes in vegetation composition and not in forest cover. At other sites, problems of local pollen representation, chronological setting, gaps in the pollen record, and local very high rainfall may have masked the $4.2 \mathrm{ka}$ event.

In southern Italy, Sicily, and Tunisia between 36 and $39^{\circ} \mathrm{N}$, a drop in AP around $4.2 \mathrm{ka}$ is always visible, and in some cases dramatic, followed by a recovery of forest vegetation in the Middle Bronze Age. We suggest that southern Italy and Tunisia were under the prevalent influence of a north African climate system characterized by a persistent high-pressure cell. At the same time, the pollen records from this region document increasing agropastoral human activity, which may have been favored by a natural opening of the forest. At the end of the $4.2 \mathrm{ka}$ event, human activity was not able to hold back a new spread of forest vegetation.

In Sardinia and Corsica, no clear change in vegetation is observed at the same time, although the pollen record suggests possible changes in the prevalent provenance of winds.

This review of the vegetation changes in the central Mediterranean region during the $4.2 \mathrm{ka}$ event points to a general vulnerability of forest communities south of $43^{\circ} \mathrm{N}$, and 
especially south of $39^{\circ} \mathrm{N}$, in response to arid events. The northward displacement of the north African high pressures over the Italian Peninsula, also at present often affecting the annual hydroclimate regime, may have induced a dramatic change in forest ecosystems during the $4.2 \mathrm{ka}$ event and may be responsible for similar ecological disruptions in the future.

Data availability. All data needed to evaluate the conclusions in the paper are presented in the paper. Additional data related to this paper may be requested from the authors.

Author contributions. FDR and DM contributed equally to conceiving this review and writing the paper.

Competing interests. The authors declare that they have no conflict of interest.

Special issue statement. This article is part of the special issue "The $4.2 \mathrm{ka}$ BP climatic event". It is a result of "The $4.2 \mathrm{kaBP}$ Event: An International Workshop", Pisa, Italy, 10-12 January 2018.

Acknowledgements. This research has been supported by the Project of Strategic Interest NextData PNR 2011e2013 (http://www.nextdataproject.it, last access: 8 January 2019) and by a project of the Sapienza University of Rome, no. RM11715C820D1E6F.

Edited by: Giovanni Zanchetta

Reviewed by: Anna Maria Mercuri and Willy Tinner

\section{References}

Allen, J. R. M., Watts, W. A., McGee, E., and Huntley, B.: Holocene environmental variability - the record from Lago Grande di Monticchio, Italy, Quatern. Int., 88, 69-80, 2002.

Attorre, F., Alfo', M., Sanctis, M. D., Francesconi, F., and Bruno, F.: Comparison of interpolation methods for mapping climatic and bioclimatic variables at regional scale, Int. J. Climatol., 27, 1825-1843, https://doi.org/10.1002/joc.1495, 2007.

Attorre, F., Francesconi, F., Valenti, R., collalti, A., and Bruno, F.: Produzione di mappe climatiche e bioclimatiche mediante Universal Kriging con deriva esterna: teoria ed esempi per l'italia, Forest - Journal of Silviculture and Forest Ecology, 5, 8-19, 2008.

Beffa, G., Pedrotta, T., Colombaroli, D., Henne, P. D., van Leeuwen, J. F. N., Süsstrunk, P., Kaltenrieder, P., Adolf, C., Vogel, H., Pasta, S., Anselmetti, F. S., Gobet, E., and Tinner, W.: Vegetation and fire history of coastal north-eastern Sardinia (Italy) under changing Holocene climates and land use, Veg. Hist. Archaeobot., 25, 271-289, https://doi.org/10.1007/s00334-0150548-5, 2016.
Behre, K.-E.: The interpretation of anthropogenic indicators in pollen diagrams, Pollen et spores, 23, 225-245, 1981.

Ben Tiba, B.: Cinq millénaires d'histoire de la végétation à Djebel El Ghorra, CIFEG, Publ. Occas., Orléans, 1995.

Bennett, K. D.: “psimpoll” and "pscomb": C programs for analysing pollen data and plotting pollen diagrams (version 4.27), Queen's University Quaternary Geology program, available at: http://www.chrono.qub.ac.uk/psimpoll/psimpoll.html (last access: 20 July 2018), 2009.

Benslimane, M., Hamimed, A., Zerey, W. E., Khaldi, A., and Mederbal, K.: Analyse et suivi du phénomène de la désertification en Algérie du nord, VertigO - la revue électronique en sciences de l'environnement, 8, 3, https://doi.org/10.4000/vertigo.6782, 2009.

Bini, M., Zanchetta, G., Persoiu, A., Cartier, R., Català, A., Cacho, I., Dean, J. R., Di Rita, F., Drysdale, R. N., Finnè, M., Isola, I., Jalali, B., Lirer, F., Magri, D., Masi, A., Marks, L., Mercuri, A. M., Peyron, O., Sadori, L., Sicre, M.-A., Welc, F., Zielhofer, C., and Brisset, E.: The $4.2 \mathrm{kaBP}$ Event in the Mediterranean Region: an overview, Clim. Past Discuss., https://doi.org/10.5194/cp-2018-147, in review, 2018.

Bisculm, M., Colombaroli, D., Vescovi, E., van Leeuwen, J. F. N., Henne, P. D., Rothen, J., Procacci, G., Pasta, S., La Mantia, T., and Tinner, W.: Holocene vegetation and fire dynamics in the supra-mediterranean belt of the Nebrodi Mountains (Sicily, Italy), J. Quaternary Sci., 27, 687-698, https://doi.org/10.1002/jqs.2551, 2012.

Branch, N. P.: Early-Middle Holocene vegetation history, climate change and human activities at Lago Riane (Ligurian Apennines, NW Italy), Veg. Hist. Archaeobot., 22, 315-334, https://doi.org/10.1007/s00334-012-0384-9, 2013.

Burjachs, F., Pérez-Obiol, R., Picornell-Gelabert, L., Revelles, J., Servera-Vives, G., Expósito, I., and Yll, E.-I.: Overview of environmental changes and human colonization in the Balearic Islands (Western Mediterranean) and their impacts on vegetation composition during the Holocene, J. Archaeol. Sci., 12, 845-859, https://doi.org/10.1016/j.jasrep.2016.09.018, 2017.

Calò, C., Henne, P. D., Curry, B., Magny, M., Vescovi, E., La Mantia, T., Pasta, S., Vannière, B., and Tinner, W.: Spatio-temporal patterns of Holocene environmental change in southern Sicily, Palaeogeogr. Palaeocl., 323-325, 110-122, https://doi.org/10.1016/j.palaeo.2012.01.038, 2012.

Caroli, I. and Caldara, M.: Vegetation history of Lago Battaglia (eastern Gargano coast, Apulia, Italy) during the middlelate Holocene, Veg. Hist. Archaeobot., 16, 317-327, https://doi.org/10.1007/s00334-006-0045-y, 2007.

Carrión, J. S., Fernández, S., González-Sampériz, P., Gil-Romera, G., Badal, E., Carrión-Marco, Y., López-Merino, L., López-Sáez, J. A., Fierro, E., and Burjachs, F.: Expected trends and surprises in the Lateglacial and Holocene vegetation history of the Iberian Peninsula and Balearic Islands, Rev. Palaeobot. Palyno., 162, 458-475, https://doi.org/10.1016/j.revpalbo.2009.12.007, 2010.

Colombaroli, D., Marchetto, A., and Tinner, W.: Long-term interactions between Mediterranean climate, vegetation and fire regime at Lago di Massaciuccoli (Tuscany, Italy), J. Ecol., 95, 755-770, https://doi.org/10.1111/j.1365-2745.2007.01240.x, 2007.

Cruise, G. M., Macphail, R. I., Linderholm, J., Maggi, R., and Marshall, P. D.: Lago di Bargone, Liguria, N Italy: a reconstruction 
of Holocene environmental and land-use history, Holocene, 19 987-1003, https://doi.org/10.1177/0959683609343142, 2009.

Cullen, H. M., Hemming, S., Hemming, G., Brown, F. H., Guilderson, T., and Sirocko, F.: Climate change and the collapse of the Akkadian empire: Evidence from the deep sea, Geology, 28, 379-382, 2000.

Currás, A., Ghilardi, M., Peche-Quilichini, K., Fagel, N., Vacchi, M., Delanghe, D., Dussouillez, P., Vella, C., Bontempi, J. M., and Ottaviani, J.-C.: Reconstructing past landscapes of the eastern plain of Corsica (NW Mediterranean) during the last 6000 years based on molluscan, sedimentological and palynological analyses, J. Archaeol. Sci., 12, 755-769, https://doi.org/10.1016/j.jasrep.2016.09.016, 2017.

Curry, B., Henne, P. D., Mesquita-Joanes, F., Marrone, F., Pieri, V., La Mantia, T., Calò, C., and Tinner, W.: Holocene paleoclimate inferred from salinity histories of adjacent lakes in southwestern Sicily (Italy), Quaternary Sci. Rev., 150, 67-83, https://doi.org/10.1016/j.quascirev.2016.08.013, 2016.

Di Rita, F.: A possible solar pacemaker for Holocene fluctuations of a salt-marsh in southern Italy, Quatern. Int., 288, 239-248, 2013.

Di Rita, F. and Magri, D.: Holocene drought, deforestation and evergreen vegetation development in the central Mediterranean: a 5500 year record from Lago Alimini Piccolo, Apulia, southeast Italy, Holocene, 19, 295-306, https://doi.org/10.1177/0959683608100574, 2009.

Di Rita, F. and Magri, D.: An overview of the Holocene vegetation history from the central Mediterranean coasts, Journal of Mediterranean Earth Sciences, 4, 35-52, 2012.

Di Rita, F. and Melis, R. T.: The cultural landscape near the ancient city of Tharros (central West Sardinia): vegetation changes and human impact, J. Archaeol. Sci., 40, 4271-4282, https://doi.org/10.1016/j.jas.2013.06.027, 2013.

Di Rita, F., Celant, A., and Magri, D.: Holocene environmental instability in the wetland north of the Tiber delta (Rome, Italy): sea-lake-man interactions, J. Paleolimnol., 44, 51-67, https://doi.org/10.1007/s10933-009-9385-9, 2010.

Di Rita, F., Simone, O., Caldara, M., Gehrels, W. R., and Magri, D.: Holocene environmental changes in the coastal Tavoliere Plain (Apulia, southern Italy): A multiproxy approach, Palaeogeogr. Palaeocl., 310, 139-151, https://doi.org/10.1016/j.palaeo.2011.06.012, 2011.

Di Rita, F., Celant, A., and Conati Barbaro, C.: Interazioni tra clima, ambiente e uomo nell'evoluzione olocenica del delta del Tevere: dati paleobotanici e ritrovamenti archeologici, Rendiconti Online della Società Geologica Italiana, 18, 19-23, 2012.

Di Rita, F., Celant, A., Milli, S., and Magri, D.: Late glacial-early Holocene vegetation history of the Tiber delta (Rome, Italy) under the influence of climate change and sea level rise, Rev. Palaeobot. Palyno., 218, 204-2016, https://doi.org/10.1016/j.revpalbo.2014.12.005, 2015.

Di Rita, F., Fletcher, W. J., Aranbarri, J., Margaritelli, G., Lirer, F., and Magri, D.: Holocene forest dynamics in central and western Mediterranean: periodicity, spatio-temporal patterns and climate influence, Sci. Rep.-UK, 8, 8929, https://doi.org/10.1038/s41598-018-27056-2, 2018a.

Di Rita, F., Lirer, F., Bonomo, S., Cascella, A., Ferraro, L., Florindo, F., Insinga, D. D., Lurcock, P. C., Margaritelli, G., Petrosino, P., Rettori, R., Vallefuoco, M., and Magri, D.: Late Holocene forest dynamics in the Gulf of Gaeta (central Mediterranean) in rela- tion to NAO variability and human impact, Quaternary Sci. Rev., 179, 137-152, https://doi.org/10.1016/j.quascirev.2017.11.012, 2018 b.

Di Rita, F., Molisso, F., and Sacchi, M.: Late Holocene environmental dynamics, vegetation history, human impact, and climate change in the ancient Literna Palus (Lago Patria; Campania, Italy), Rev. Palaeobot. Palyno., 258, 48-61, https://doi.org/10.1016/j.revpalbo.2018.06.005, 2018c.

Dixit, Y., Hodell, D. A., and Petrie, C. A.: Abrupt weakening of the summer monsoon in northwest India 4100 yr ago, Geology, 42, 339-342, https://doi.org/10.1130/G35236.1, 2014.

Dixit, Y., Hodell, D. A., Giesche, A., Tandon, S. K., Gázquez, F., Saini, H. S., Skinner, L. C., Mujtaba, S. A. I., Pawar, V., Singh, R. N., and Petrie, C. A.: Intensified summer monsoon and the urbanization of Indus Civilization in northwest India, Sci. Rep.UK, 8, https://doi.org/10.1038/s41598-018-22504-5, 2018.

Drescher-Schneider, R., de Beaulieu, J.-L., Magny, M., WalterSimonnet, A.-V., Bossuet, G., Millet, L., Brugiapaglia, E., and Drescher, A.: Vegetation history, climate and human impact over the last 15000 years at Lago dell'Accesa (Tuscany, Central Italy), Veg. Hist. Archaeobot., 16, 279-299, https://doi.org/10.1007/s00334-006-0089-z, 2007.

Guido, M. A., Menozzi, B. I., Bellini, C., Placereani, S., and Montanari, C.: A palynological contribution to the environmental archaeology of a Mediterranean mountain wetland (North West Apennines, Italy), Holocene, 23, 1517-1527, https://doi.org/10.1177/0959683613496294, 2013.

Isola, I., Zanchetta, G., Drysdale, R. N., Regattieri, E., Bini, M., Bajo, P., Hellstrom, J. C., Baneschi, I., Lionello, P., Woodhead, J., and Greig, A.: The 4.2 ka event in the central Mediterranean: new data from a Corchia speleothem (Apuan Alps, central Italy), Clim. Past, 15, 135-151, https://doi.org/10.5194/cp15-135-2019, 2019.

Joannin, S., Brugiapaglia, E., de Beaulieu, J.-L., Bernardo, L., Magny, M., Peyron, O., Goring, S., and Vannière, B.: Pollenbased reconstruction of Holocene vegetation and climate in southern Italy: the case of Lago Trifoglietti, Clim. Past, 8, 19731996, https://doi.org/10.5194/cp-8-1973-2012, 2012.

Kaniewski, D., Marriner, N., Cheddadi, R., Guiot, J., and Van Campo, E.: The 4.2 ka BP event in the Levant, Clim. Past, 14, 1529-1542, https://doi.org/10.5194/cp-14-1529-2018, 2018.

Lawson, I., Frogley, M., Bryant, C., Preece, R., and Tzedakis, P.: The Lateglacial and Holocene environmental history of the Ioannina basin, north-west Greece, Quaternary Sci. Rev., 23, 1599_ 1625, https://doi.org/10.1016/j.quascirev.2004.02.003, 2004.

Liu, F. and Feng, Z.: A dramatic climatic transition at $\sim 4000$ cal. yr BP and its cultural responses in Chinese cultural domains, Holocene, 22, 1181-1197, https://doi.org/10.1177/0959683612441839, 2012.

López-Moreno, J. I., Vicente-Serrano, S. M., Morán-Tejeda, E., Lorenzo-Lacruz, J., Kenawy, A., and Beniston, M.: Effects of the North Atlantic Oscillation (NAO) on combined temperature and precipitation winter modes in the Mediterranean mountains: observed relationships and projections for the 21st century, Global Planet. Change, 77, 62-76, 2011.

Magny, M., Combourieu-Nebout, N., de Beaulieu, J. L., BoutRoumazeilles, V., Colombaroli, D., Desprat, S., Francke, A., Joannin, S., Ortu, E., Peyron, O., Revel, M., Sadori, L., Siani, G., Sicre, M. A., Samartin, S., Simonneau, A., Tinner, W., Vannière, 
B., Wagner, B., Zanchetta, G., Anselmetti, F., Brugiapaglia, E., Chapron, E., Debret, M., Desmet, M., Didier, J., Essallami, L., Galop, D., Gilli, A., Haas, J. N., Kallel, N., Millet, L., Stock, A., Turon, J. L., and Wirth, S.: North-south palaeohydrological contrasts in the central Mediterranean during the Holocene: tentative synthesis and working hypotheses, Clim. Past, 9, 20432071, https://doi.org/10.5194/cp-9-2043-2013, 2013.

Magri, D.: Late-Quaternary changes of plant biomass as recorded by pollen-stratigraphical data: a discussion of the problem at Valle di Castiglione, Italy, Rev. Palaeobot. Palyno., 81, 313-325, 1994.

Magri, D.: Some questions on the late-Holocene vegetation of Europe, Holocene, 5, 354-360, 1995.

Magri, D.: Late Quaternary vegetation history at Lagaccione near Lago di Bolsena (central Italy), Rev. Palaeobot. Palyno., 106, 171-208, 1999.

Magri, D. and Parra, I.: Late Quaternary western Mediterranean pollen records and African winds, Earth Planet. Sc. Lett., 200, 401-408, 2002.

Magri, D. and Sadori, L.: Late Pleistocene and Holocene pollen stratigraphy at Lago di Vico, central Italy, Veg. Hist. Archaeobot., 8, 247-260, 1999.

Magri, D., Agrillo, E., Di Rita, F., Furlanetto, G., Pini, R., Ravazzi, C., and Spada, F.: Holocene dynamics of tree taxa populations in Italy, Rev. Palaeobot. Palyno., 218, 267-284, https://doi.org/10.1016/j.revpalbo.2014.08.012, 2015.

Magri, D., Di Rita, F., Aranbarri, J., Fletcher, W., and GonzálezSampériz, P.: Quaternary disappearance of tree taxa from Southern Europe: Timing and trends, Quaternary Sci. Rev., 163, 23-55, https://doi.org/10.1016/j.quascirev.2017.02.014, 2017.

Margaritelli, G., Vallefuoco, M., Di Rita, F., Capotondi, L., Bellucci, L. G., Insinga, D. D., Petrosino, P., Bonomo, S., Cacho, I., Cascella, A., Ferraro, L., Florindo, F., Lubritto, C., Lurcock, P. C., Magri, D., Pelosi, N., Rettori, R., and Lirer, F.: Marine response to climate changes during the last five millennia in the central Mediterranean Sea, Global Planet. Change, 142, 53-72, https://doi.org/10.1016/j.gloplacha.2016.04.007, 2016.

Mariotti Lippi, M. Florenzano, A., Rinaldi, R., Allevato, E., Arobba, D., Bacchetta, G., Bal, M.-C., Bandini Mazzanti, M., Benatti, A., Beneš, J., Bosi, G., Buonincontri, M., Caramiello, R., Castelletti, L., Castiglioni, E., Celant, A., Clò, E., Costantini, L., Di Pasquale, G., Di Rita, F., Fiorentino, G., Furlanetto, G., Giardini, M., Grillo, O., Guido, M., Herchenbach, M., Magri, D., Marchesini, M., Maritan, M., Marvelli, S., Masi, A., Miola, A., Montanari, C., Montecchi, M.C., Motella, S., Nisbet, R., Orrù, M., Peña Chocarro, L., Pepe, C., Perego, R., Rattighieri, E., Ravazzi, C., Rottoli, M., Rowan, E., Sabato, D., Sadori, L., Sarigu, M., Torri, P., Ucchesu, M., and Mercuri, A. M.: The Botanical Record of Archaeobotany Italian Network - BRAIN: a cooperative network, database and website, Flora Mediterranea, 28, 365-374,, https://doi.org/10.7320/FlMedit28.365, 2018.

Marshall, M. H., Lamb, H. F., Huws, D., Davies, S. J., Bates, R., Bloemendal, J., Boyle, J., Leng, M. J., Umer, M., and Bryant, C.: Late Pleistocene and Holocene drought events at Lake Tana, the source of the Blue Nile, Global Planet. Change, 78, 147-161, https://doi.org/10.1016/j.gloplacha.2011.06.004, 2011.

Martín-Puertas, C., Valero-Garcés, B. L., Pilar Mata, M., GonzálezSampériz, P., Bao, R., Moreno, A. and Stefanova, V.: Arid and humid phases in southern Spain during the last 4000 years: the Zoñar Lake record, Córdoba, Holocene, 18, 907-921, https://doi.org/10.1177/0959683608093533, 2008.

Mercuri, A. M.: Genesis and evolution of the cultural landscape in central Mediterranean: the "where, when and how" through the palynological approach, Landscape Ecol., 29, 1799-1810, https://doi.org/10.1007/s10980-014-0093-0, 2014.

Mercuri, A. M., Mazzanti, M. B., Torri, P., Vigliotti, L., Bosi, G., Florenzano, A., Olmi, L., and N'siala, I. M.: A marine/terrestrial integration for mid-late Holocene vegetation history and the development of the cultural landscape in the Po valley as a result of human impact and climate change, Veg. Hist. Archaeobot., 21, 353-372, https://doi.org/10.1007/s00334-012-0352-4, 2012.

Natali, E. and Forgia, V.: The beginning of the Neolithic in Southern Italy and Sicily, Quatern. Int., 470, 253-269, https://doi.org/10.1016/j.quaint.2017.07.004, 2018.

Noti, R., van Leeuwen, J. F. N., Colombaroli, D., Vescovi, E., Pasta, S., La Mantia, T., and Tinner, W.: Mid- and late-Holocene vegetation and fire history at Biviere di Gela, a coastal lake in southern Sicily, Italy, Veg. Hist. Archaeobot., 18, 371-387, https://doi.org/10.1007/s00334-009-0211-0, 2009.

Oldfield, F., Asioli, A., Accorsi, C. A., Mercuri, A. M., Juggins, S., Langone, L., Rolph, T., Trincardi, F., Wolff, G., Gibbs, Z., Vigliotti, L., Frignani, M., van der Post, K., and Branch, N.: A high resolution late Holocene palaeo environmental record from the central Adriatic Sea, Quaternary Sci. Rev., 22, 319-342, 2003.

Olsen, J., Anderson, N. J., and Knudsen, M. F.: Variability of the North Atlantic Oscillation over the past 5200 years, Nat. Geosci., 5, 808-812, 2012.

Pinto, J. G., Ulbrich, U., Leckebusch, G. C., Spangeh, T., Reyers, M., and Zacharias, S.: Changes in storm track and cyclone activity in three SRES ensemble experiments with the ECHAM5/MPI-OM1 GCM, Clim. Dynam., 29, 195-210, 2007.

Poher, Y.: Dynamique de la biodiversité et changements environnementaux en Corse depuis 7000 ans: éclairages paléoentomologiques et paléobotaniques, Biodiversité et Ecologie, Aix Marseille Université, 2017.

Poher, Y., Ponel, P., Médail, F., Andrieu-Ponel, V., and Guiter, F.: Holocene environmental history of a small Mediterranean island in response to sea-level changes, climate and human impact, Palaeogeogr. Palaeocl., 465, 247-263, https://doi.org/10.1016/j.palaeo.2016.10.037, 2017.

Radi, G. and Petrinelli Pannocchia, C.: The beginning of the Neolithic era in Central Italy, Quatern. Int., 470, 270-284, https://doi.org/10.1016/j.quaint.2017.06.063, 2018.

Reille, M.: New pollen-analytical researches in Corsica: the problem of Quercus ilex L. and Erica arborea L., the origin of Pinus halepensis Miller forests, New Phytol., 122, 359-378, 1992.

Reille, M., Gamisans, J., Andrieu-Ponel, V., and de Beaulieu, J.-L.: The Holocene at Lac de Creno, Corsica, France: a key site for the whole island, New Phytol., 141, 291-307, 1999.

Sadori, L. and Narcisi, B.: The Postglacial record of environmental history from Lago di Pergusa, Sicily, Holocene, 11, 655-671, 2001.

Smaoui, A.: Bioclimat et Végétation de la Tunisie et des régions prospectées pendant le 12ème ITER Mediterraneum de OPTIMA, Bocconea, 27, 13-20, https://doi.org/10.7320/Bocc27.1.013, 2015. 
Stambouli-Essassi, S., Roche, E., and Bouzid, S.: Evolution de la végétation et du climat dans le Nord-ouest de la Tunisie au cours des 40 derniers millénaires, Geo-Eco-Trop, 31, 171-214, 2007.

Staubwasser, M., Sirocko, F., Grootes, P. M., and Segl, M.: Climate change at the $4.2 \mathrm{ka}$ BP termination of the Indus valley civilization and Holocene south Asian monsoon variability, Geophys. Res. Lett., 30, https://doi.org/10.1029/2002GL016822, 2003.

Tinner, W., Lotter, A. F., Ammann, B., Conedera, M., Hubschmid, P., van Leeuwen, J. F. N., and Wehrli, M.: Climatic change and contemporaneous land-use phases north and south of the Alps $2300 \mathrm{BC}$ to $800 \mathrm{AD}$, Quaternary Sci. Rev., 22, 1447-1460, https://doi.org/10.1016/S0277-3791(03)00083-0, 2003.

Tinner, W., van Leeuwen, J. F. N., Colombaroli, D., Vescovi, E., van der Knaap, W. O., Henne, P. D., Pasta, S., D'Angelo, S., and La Mantia, T.: Holocene environmental and climatic changes at Gorgo Basso, a coastal lake in southern Sicily, Italy, Quaternary Sci. Rev., 28, 1498-1510, https://doi.org/10.1016/j.quascirev.2009.02.001, 2009.

Tinner, W., Vescovi, E., van Leeuwen, J. F. N., Colombaroli, D., Henne, P. D., Kaltenrieder, P., Morales-Molino, C., Beffa, G., Gnaegi, B., van der Knaap, W. O., La Mantia, T., and Pasta, S.: Holocene vegetation and fire history of the mountains of Northern Sicily (Italy), Veg. Hist. Archaeobot., 25, 499-519, https://doi.org/10.1007/s00334-016-0569-8, 2016.

Trigo, I. F., Bigg, G. R., and Davies, T. D.: Climatology of cyclogenesis mechanisms in the Mediterranean, Mon. Weather Rev., 130, 549-569, 2002.

Trigo, R. M., Pozo-Vázquez, D., Osborn, T. J., Castro-Díez, Y., Gámiz-Fortis, S., and Esteban-Parra, M. J.: North Atlantic oscillation influence on precipitation, river flow and water resources in the Iberian Peninsula, Int. J. Climatol., 24, 925-944, 2004.

Trouet, V., Esper, J., Graham, N. E., Baker, A., Scourse, J. D., and Frank, D. C.: Persistent positive north Atlantic oscillation mode dominated the medieval climate anomaly, Science, 324, 78-80, 2009.

Vannière, B., Colombaroli, D., Chapron, E., Leroux, A., Tinner, W., and Magny, M.: Climate versus human-driven fire regimes in Mediterranean landscapes: the Holocene record of Lago dell'Accesa (Tuscany, Italy), Quaternary Sci. Rev., 27, 11811196, https://doi.org/10.1016/j.quascirev.2008.02.011, 2008.

Vescovi, E., Kaltenrieder, P., and Tinner, W.: Late-Glacial and Holocene vegetation history of Pavullo nel Frignano (Northern Apennines, Italy), Rev. Palaeobot. Palyno., 160, 32-45, https://doi.org/10.1016/j.revpalbo.2010.01.002, 2010a.
Vescovi, E., Ammann, B., Ravazzi, C., and Tinner, W.: A new Late-glacial and Holocene record of vegetation and fire history from Lago del Greppo, northern Apennines, Italy, Veg. Hist. Archaeobot., 19, 219-233, https://doi.org/10.1007/s00334-0100243-5, $2010 \mathrm{~b}$.

Vicente-Serrano, S. M. and J. I. López-Moreno: The nonstationary influence of the North Atlantic Oscillation on European precipitation, J. Geophys. Res., 113, D20120 https://doi.org/10.1029/2008JD010382, 2008.

Walker, M. J. C., Berkelhammer, M., Björck, S., Cwynar, L. C., Fisher, D. A., Long, A. J., Lowe, J. J., Newnham, R. M., Rasmussen, S. O., and Weiss, H.: Formal subdivision of the Holocene Series/Epoch: a Discussion Paper by a Working Group of INTIMATE (Integration of ice-core, marine and terrestrial records) and the Subcommission on Quaternary Stratigraphy (International Commission on Stratigraphy), J. Quaternary Sci., 27, 649-659, https://doi.org/10.1002/jqs.2565, 2012.

Watson, C. S.: The vegetational history of the northern Apennines, Italy: information from three new sequences and a review of regional vegetational change, J. Biogeogr., 23, 805-841, 1996.

Weiss, H.: 4.2 ka BP Megadrought and the Akkadian Collapse, Megadrought and Collapse: From Early Agriculture to Angkor, edited by: Weiss, H., University Press, Oxford, UK, 93-160, 2017.

Weiss, H., Courty, M.-A., Wetterstrom, W., Guichard, F., Senior, L., Meadow, R., and Curnow, A.: The Genesis and Collapse of Third Millennium North Mesopotamian Civilization, Science, 261, 995-1004, https://doi.org/10.1126/science.261.5124.995, 1993.

Yll, E.-I., Perez-Obiol, R., Pantaleon-Cano, J., and Roure, J. M.: Palynological evidence for climatic change and human activity during the Holocene on Minorca (Balearic Islands), Quaternary Res., 48, 339-347, 1997.

Zielhofer, C., Fletcher, W. J., Mischke, S., De Batist, M., Campbell, J. F. E., Joannin S., Tjallingii, R., El Hamouti, N., Junginger, A., Stele. A., Bussmann, J., Schneider, B., Lauer, T., Spitzer, K., Strupler, M., Brachert, T., and Mikdad, A.: Atlantic forcing of Western Mediterranean winter rain minima during the last 12000 years, Quaternary Sci. Rev., 157, 29-51, 2017.

Zielhofer, C., Köhler, A., Mischke, S., Benkaddour, A., Mikdad, A., and Fletcher, W. J.: Western Mediterranean hydro-climatic consequences of Holocene iceberg advances (Bond events), Clim. Past Discuss., https://doi.org/10.5194/cp-2018-97, in review, 2018. 